\title{
Optimising soil physical properties for rehabilitation of mined land - effects of tine type on soil strength and root proliferation
}

\author{
T.D. Lardner School of Earth and Environment, The University of Western Australia, Australia
}

T.R. Worthington BHP Billiton Worsley Alumina Pty Ltd, Australia

M.F. Braimbridge Outback Ecology Pty Ltd, Australia

S. Vlahos BHP Billiton Worsley Alumina Pty Ltd, Australia

M. Tibbett National Soil Resources Institute, Cranfield University, United Kingdom

\begin{abstract}
Deep ripping of mine floors after bauxite mining is standard practice carried out prior to overburden and topsoil return to alleviate the soil compaction caused by trafficking of heavy machinery. A field trial was conducted to compare the effects of deep ripping practices using straight and winged tines, with an un-ripped control, on the physical properties of regolith within three rehabilitated bauxite mine pits. The subsequent effect on root development was also assessed two years after deep ripping. Ripping reduced soil strength and increased root abundance and depth of root penetration, irrespective of the type of pit floor materials present. However, there was a contrast in tine performance depending on the materials being ripped. The winged tine produced significantly lower penetration resistance in more friable, sandy soils, while the straight tine outperformed the winged tine in heavier, more clayey soils. Despite the differences in soil strength reduction between tine types in these different materials, there was no corresponding difference in root proliferation. Provided that soil strength was reduced to a critical threshold (about $35 \mathrm{~N}$ or less) over a sufficient area, roots proliferate to a similar extent, regardless of whether there are zones of lower strength present. The benefits conferred by deep ripping appeared to be highly dependent on the physical properties of the soil materials present so the effects of deep ripping will not necessarily be consistent across all rehabilitation areas.
\end{abstract}

\section{Introduction}

Deep ripping of bauxite mine pit floors prior to overburden and topsoil return is carried out to alleviate soil compaction resulting from trafficking of heavy machinery during mining activities (Tibbett, 2010; Koch, 2007). This is done as part of the standard rehabilitation prescription and is designed to facilitate increased root exploration of regolith materials (Kew et al., 2007; Szota et al., 2007). At the Boddington Bauxite Mine $(\mathrm{BBM})$ in south Western Australia, ripping is currently undertaken using a straight, chisel tine; however, it has been demonstrated that under certain conditions its use can actually increase compaction at depth due to plastic failure of regolith materials during ripping (Croton and Ainsworth, 2007; Kew et al., 2007; Godwin and Spoor, 1977). This phenomenon arises when ripping is conducted to a depth where the failure zone of the soil materials is located part-way up the tine shank rather that just above the tine point where maximum lift occurs (Godwin and Spoor, 1977). This results in the soil materials below the failure zone being pushed ahead of the tine shank and to the sides creating a slot like void surrounded by compacted soil (Croton and Ainsworth, 2007; Spoor, 2006). Godwin and Spoor (1977) examined this and identified contributing factors to what they termed critical depth. The critical depth of ripping is dependent on tine width and shape, soil type and soil water content (Croton and Ainsworth, 2007; Godwin and Spoor, 1977). The latter restricts ripping operations to summer and autumn months when soils are driest and can occasionally necessitate suspension of rehabilitation works in the event of summer rainfall (Croton and Ainsworth, 2007).

The use of a winged tine has been considered for pit floor ripping because it has been shown to increase critical depth and soil tillage regardless of soil water content (Croton and Ainsworth, 2007; Ahmed and Godwin, 1983; Spoor and Godwin, 1978). Previous studies of various winged tine configurations and their efficacy in the field have noted trade-offs between the aforementioned advantages and an increase in 
required draught force (Godwin, 2007; Lacey et al., 2001) and a greater propensity for breakages resulting from damage to tine wings (Croton and Ainsworth, 2007). Other investigations have used measurements of various soil physical properties to evaluate deep ripping in agricultural soils and post mining materials (Kew et al., 2007; Lacey et al., 2001; Moffat and Boswell, 1997; Spoor and Godwin, 1978), but no published studies have compared the use of different tine types in ripping a range of regolith materials and few have measured the effectiveness of deep ripping in promoting root proliferation and penetration, particularly in forest systems; Szota et al. (2007) being a notable exception.

To address these matters more broadly, we established a field trial in 2005 to investigate the physical impact of ripping and whether the use of a winged tine positively affects root proliferation in comparison with a straight tine. We anticipated that the winged tine would have a greater impact on a broad range of regolith materials and would promote greater root colonisation than the straight tine.

\section{$2 \quad$ Methods}

\subsection{Experimental design and trial establishment}

The field trial was established at three sites within the BHP Billiton Worsley Alumina mining lease located within the jarrah forest of the Darling Range near Boddington south east of Perth, Western Australia. A section of each site (hereafter referred to as Pit 1, Pit 2, and Pit 3) was divided into three separate plots. Each plot received one of three deep ripping treatments: straight tine ripping; winged tine ripping; and no ripping (control). Pits 1 and 2 were ripped in October and November 2004 respectively and Pit 3 was ripped almost a year later in September 2005. Rip line spacing in the two ripping treatments was between 1.5 and $2 \mathrm{~m}$. The location of the treatment plots was not randomised within the pits owing to the limitations of machinery movement, and as a result, the replicates of each treatment were spatially grouped. After deep ripping, overburden and topsoil materials were replaced; generally to a depth of about $20 \mathrm{~cm}$ each although it does vary. The sites were then contour scarified and seeded with about 160 plant species that are native to the surrounding jarrah forest. Pits 1 and 2 were fertilised in August 2005 and Pit 3 was fertilised in August 2006. All experimental plots were assessed in December 2007.

\subsection{Soil sampling}

Trenches were excavated perpendicular to the rip lines through the three treatment areas within each mine pit. The position of three rip-lines within the straight tine and winged tine ripped plots were identified using GPS coordinates and three discrete areas in the non-ripped control plot were selected. At each sampling point, the working face was cleaned and the major soil and regolith materials identified. Samples of each material type were taken from two to three positions within each profile to form a composite sample which was later used for determination of chemical and physical properties.

\subsection{Characterisation of soil materials}

Distinct soil materials that were identified within the profiles of each pit were subjected to a raft of laboratory analyses appropriate to an assessment of their hospitality to plant roots. All analyses were conducted on three replicates of air dried material that had been passed through a $2 \mathrm{~mm}$ sieve unless otherwise stated. Measurements of soil $\mathrm{pH}$ and EC were made on 1:5 soil:water extracts for EC and 1:5 soil: $0.01 \mathrm{M} \mathrm{CaCl} 2$ extracts for $\mathrm{pH}$ following methods detailed in Rayment and Higginson (1992). Particle size distribution was determined using the pipette method described in Gee and Bauder (1986). The texture of each soil material was determined by comparing the percentages of sand, silt and clay in the material against a standard texture diagram (McDonald and Isbell, 1990). The analysis was performed on a single composite sample of each material $(n=1)$. Single samples $(n=1)$ of each material were analysed by $X$-ray diffraction (XRD) to determine their mineralogy. A Philips PW1830 X-ray diffractometer with Cu target tube was used. Mounts of finely ground material were prepared and diffraction patterns were determined for the range $2-70^{\circ}$ at a scan rate of 0.02 . For mineral identification, the spacings and intensities of the diffraction traces were compared with those for the appropriate minerals given in JCPDS (Joint Committee on Powder Diffraction Standards) data files. The Emerson aggregate test, a measure of structural stability, was used to determine the propensity for dry aggregates of each material to slake and disperse on wetting (Emerson, 2002). 


\subsection{Soil strength and root abundance}

For each mine pit, a $1 \mathrm{~m}^{2}$ quadrat, divided into $10 \mathrm{~cm}^{2}$ cells, was fixed to each described section of the trench face. Measurements of soil strength or penetration resistance were made within each cell using a Mecmesin Compact Force Gauge $200 \mathrm{~N}$ with a tip diameter of $3.12 \mathrm{~mm}$. Measurements were taken in Newton's (N) and were converted into Megapascals (Mpa) using a factor of 0.1306. The penetrometer data was used to create contour maps using SURFER ${ }^{\text {TM }}$ to provide a visual indication of the level of in situ soil strength.

The abundance of roots that were exposed through the profile was scored within each $10 \mathrm{~cm}^{2}$ cell using a scoring system developed by McDonald and Isbell (1990). Scores of root abundance were multiplied by a weighting factor according to root diameter and the products were summed to give a single root score per $10 \mathrm{~cm}^{2}$ cell. These data were used to create contour maps of root abundance using SURFER ${ }^{\mathrm{TM}}$ to illustrate root distribution and abundance across the $1 \mathrm{~m}^{2}$ area. Root abundance scores for each cell that corresponded with penetration resistances below a predetermined limit were summed and divided by the total root abundance across the whole grid. This process was repeated for penetration resistance limits that ranged between 5 and $105 \mathrm{~N}$ at intervals of $10 \mathrm{~N}$. This enabled estimates to be made of the percentage of total root abundance that results from a given penetration resistance threshold.

\subsection{Data analysis}

Penetration resistance and root abundance score data did not generally conform to the assumptions of oneway analysis of variance (ANOVA) due primarily to unequal sample sizes but also due to skewness and heteroscedacticity of data even when transformed. Differences in penetration resistance and root abundance score between ripping treatments was therefore tested by Kruskal-Wallis ANOVA on ranks and, where differences were found, post hoc testing employed Tukey's or Dunn's methods respectively depending on whether sample sizes were equal or not.

\section{Results}

\subsection{Characterisation of soil materials}

All profiles exhibited distinct topsoil, overburden, and pit floor layers. Topsoils (Material A) were variable in depth $(5-20 \mathrm{~cm})$ and had a predominantly single-grained structure with high pisolithic coarse fragment content ( $\geq 65 \%$ in Pit $1 ; \geq 70 \%$ in Pit 2; $\geq 60 \%$ in Pit 3) of diameter ranging from 2 to $20 \mathrm{~mm}$. All topsoils had a loose to very weak consistence. These materials were dominated by quartz.

Overburden materials (Material B) also varied in depth $(0-30 \mathrm{~cm})$; negligible presence in some areas of Pit 1 . They were predominantly single-grained with high coarse fragment content ( $\geq 60 \%$ in all pits). Coarse fragments ranged in diameter between 2 and $100 \mathrm{~mm}$ in Pits 1 and 3 and between 2 and $150 \mathrm{~mm}$ in Pit 2 . These materials exhibited weak to very weak consistence in all cases. Material B in Pit 1 was dominated by gibbsite and quartz. In Pit 2, Material B was composed mostly of kaolinite and in Pit 3 Material B was dominated by quartz.

Pit floor materials displayed the greatest heterogeneity within the study areas of each pit and in most cases two or more materials were identified. In Pit 1, there were three recognisable pit floor materials (Materials C, $\mathrm{D}$, and $\mathrm{E}$ ). These varied in structure, ranging from single-grained to very strong polyhedral aggregates to massive structure, and consistence varied from weak to strong. Coarse fragment content varied from 20 to $>90 \%$ with fragment diameters ranging from 2 to $200 \mathrm{~mm}$. Some mottling and iron cementation was evident from approximately $70 \mathrm{~cm}$ depth. Material $\mathrm{C}$ was composed mostly of quartz, and Materials $\mathrm{D}$ and $\mathrm{E}$ were dominated by gibbsite with Material D also containing about $25 \%$ kaolinite.

Three materials were also identified in Pit 2 (Materials C1, C2, and D) and these were generally well structured with weak to moderate polyhedral aggregates. Cutans were common on aggregate faces. Coarse fragment content was around $70 \%$ in all materials with fragment diameters ranging from 2 to $150 \mathrm{~mm}$. Consistence was weak to firm. Mineralogy of Materials C1 and C2 was similar and both were dominated by kaolinite. Mineralogy of Material D was similar to that of Material D in Pit 1.

There were two identifiable pit floor materials in Pit 3 (Materials C and D). Structure ranged from singlegrained to moderate polyhedral aggregates with very weak to firm consistence. Coarse fragment content 
varied from 20 to $80 \%$ with fragment diameters ranging from 2 to $300 \mathrm{~mm}$. Some mottling was noted from around $50 \mathrm{~cm}$ depth. Material $\mathrm{C}$ was dominated by quartz and Material D in Pit 3 was mineralogically similar to Material D in the other pits except that it lacked kaolinite.

None of the soil materials could be considered inhospitable to plant roots in terms of their $\mathrm{pH}$ and EC. All were slightly acidic with $\mathrm{pH}$ ranging from 5.3 to 5.9 across all materials in all three pits. Similarly, all materials had EC values lower than $0.85 \mathrm{dS} \mathrm{m}^{-1}$ and could therefore be classified as non saline.

Particle size analysis of the fine earth fraction revealed that the materials in Pit 3 were considerably sandier with a greater coarse fraction than the soil materials in the other two pits (Figure 1). The soil materials in Pit 3 were uniformly coarse with depth and there was little difference in texture between soil layers. In contrast, the soil materials in Pit 2 were notably finer in texture and became more clayey with depth. This trend of increasing silt and clay content with depth was similar but less acute in Pit 1 . Fine earth of pit floor materials in Pits 1 and 2 contained more than 35\% silt and clay but those of Pit 3 had less than $16 \%$ of these fractions combined.

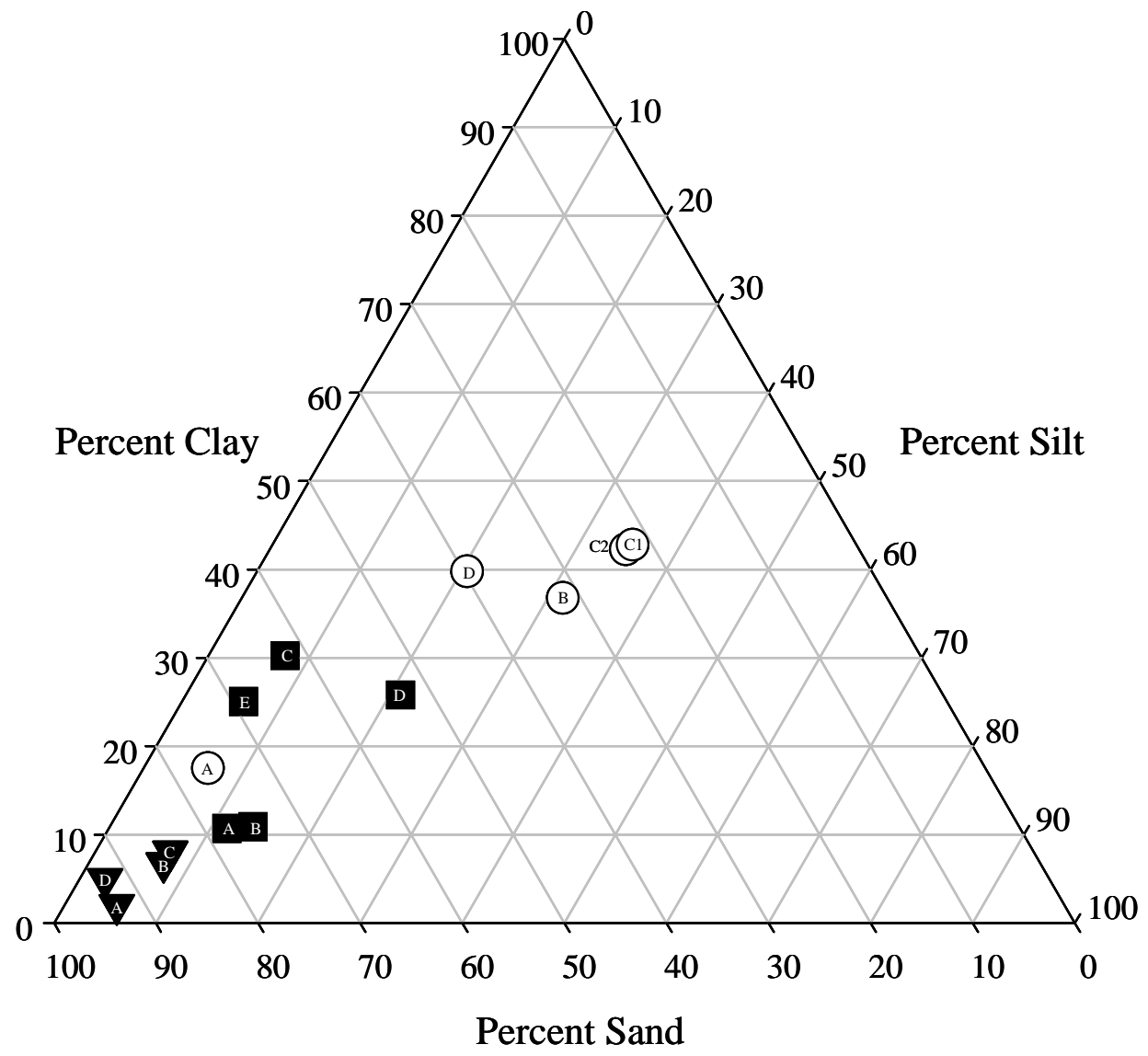

\section{Figure 1 Texture of each soil material in Pit $1(\square)$; Pit $2(Q)$; and Pit 3 ( $\nabla$ ) based on particle size analysis. Diameters for the particle size classes are: Sand, 2 to $0.02 \mathrm{~mm}$; Silt, 0.02 to $0.002 \mathrm{~mm}$ and; Clay, $<0.002 \mathrm{~mm}$}

Emerson's aggregate stability test was not conducted on Material B from Pit 3 or Material A from any of the three mine pits because they contained no aggregates due to their coarse, single-grained nature. Aggregates of the other soil materials in Pit 1 , with the exception of Material $\mathrm{C}$, were found to be highly stable and did not disperse on wetting. Material $\mathrm{C}$ from Pit 1, however, was structurally unstable because its aggregates dispersed completely on wetting. Aggregates of all soil materials in Pit 2 were highly stable; even after severe disturbance to aggregates, clay particles flocculated indicating strong, long range attractive forces between them (Emerson, 2002). Material C from Pit 3 displayed similar behaviour to that of Material C from Pit 1 and dispersed completely on wetting. Material D only dispersed slightly after remoulding at field capacity, indicating potential instability if compacted or disturbed while saturated (Emerson, 2002). 


\subsection{Soil strength and root abundance}

Deep ripping had a highly significant effect on both penetration resistance $(\mathrm{P}<0.001)$ and root abundance $(\mathrm{P}<0.001)$ in Pit 1. Overall penetration resistance within the upper $1.2 \mathrm{~m}$ of each ripping treatment differed significantly (Figure 2). Mean penetration resistance in the winged tine ripped profiles was approximately half that of un-ripped profiles, and it was also significantly lower than that of profiles ripped with the straight tine $(\mathrm{P}<0.05)$. Root abundance was comparable between the straight tine and winged tine ripped profiles but both had significantly more roots than the un-ripped, control area $(\mathrm{P}<0.05)$. In the control plots roots generally did not penetrate the substrates below about $20 \mathrm{~cm}$ (Figure 3). Ripping with both tine types had a very clear impact on the strength of the soil materials in Pit 1; the $\mathrm{v}$ shaped zone of low penetration resistance was clearly evident in the profiles of both treatments even after two years since ripping (Figure 4).

In Pit 2 there were highly significant differences in penetration resistance $(\mathrm{P}<0.001)$ and root abundance scores $(\mathrm{P}<0.001)$ between treatments. The straight tine reduced penetration resistance to a significantly greater extent than the winged tine $(\mathrm{P}<0.05$; Figure 2$)$, but root abundances were nevertheless highly comparable ( $\mathrm{P}>0.05$; Figure 2$)$. The spatial pattern of penetration resistance was similar between the two ripping treatments (Figure 4) suggesting that the straight tine has had a greater impact on the pit floor substrates in Pit 2 than in Pit 1. The soil materials in un-ripped control profiles had significantly higher penetration resistance than those ripped by both the straight tine and winged tine $(\mathrm{P}<0.05)$. Root abundance was also significantly lower in the control areas $(\mathrm{P}<0.05)$. Overall, roots were considerably more abundant in Pit 2 than in either Pit 1 or Pit 3(Figure 3).

There were also highly significant differences in both the penetration resistance $(\mathrm{P}<0.001)$ and root abundance scores $(\mathrm{P}<0.001)$ of the three treatments in Pit 3 (Figure 2). The winged tine ripped area had significantly lower soil strength than both the control and straight tine ripped plots $(\mathrm{P}<0.05)$, but there was no difference in mean penetration resistance in the latter two treatments $(\mathrm{P}>0.05)$. As was the case in Pits 1 and 2, root abundance was significantly greater in the profiles ripped by both tines compared with the control $(\mathrm{P}<0.05)$ but there was no difference in root abundance between plots that had been ripped by either tine $(\mathrm{P}>0.05)$.

Penetration resistance in the upper $65 \mathrm{~cm}$ of the profile in Pit 3 was lowest in the winged tine treatment, and greatest in the straight tine ripped treatment down to $35 \mathrm{~cm}$ (Figure 3). Below $35 \mathrm{~cm}$ penetration resistance was highest in the un-ripped controls and below $45 \mathrm{~cm}$ there was little difference in penetration resistance between the un-ripped and straight tine ripped profiles, suggesting that the straight tine has had limited impact on soil strength in the pit floor substrates of this pit. The zones of lower penetration resistance in the rip lines of Pit 3 were much less obvious than in the other two pits (Figure 4). Root abundances were low across Pit 3 in comparison with the other two pits, irrespective of treatment, and the majority of roots did not penetrate to depths greater than $30 \mathrm{~cm}$. This is most likely due to the younger age of the vegetation in this pit. 
Mean penetration resistance $(\mathbf{N})$
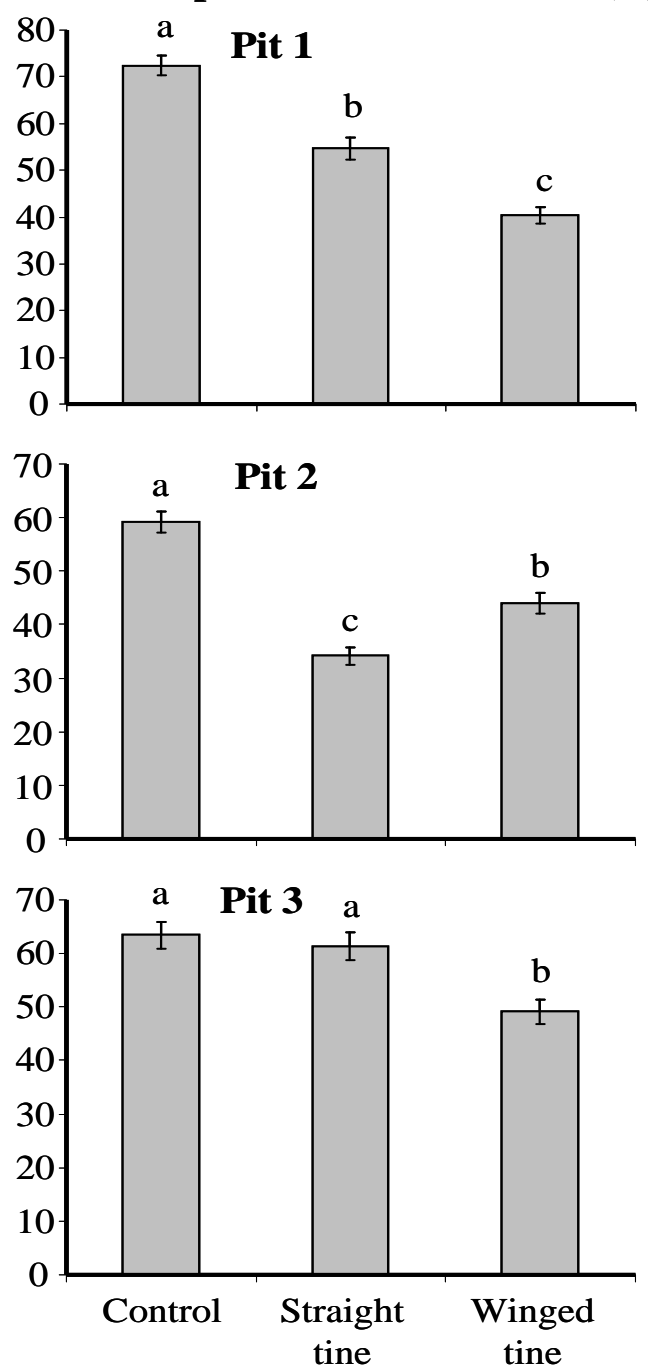

Mean root abundance score

Pit 1
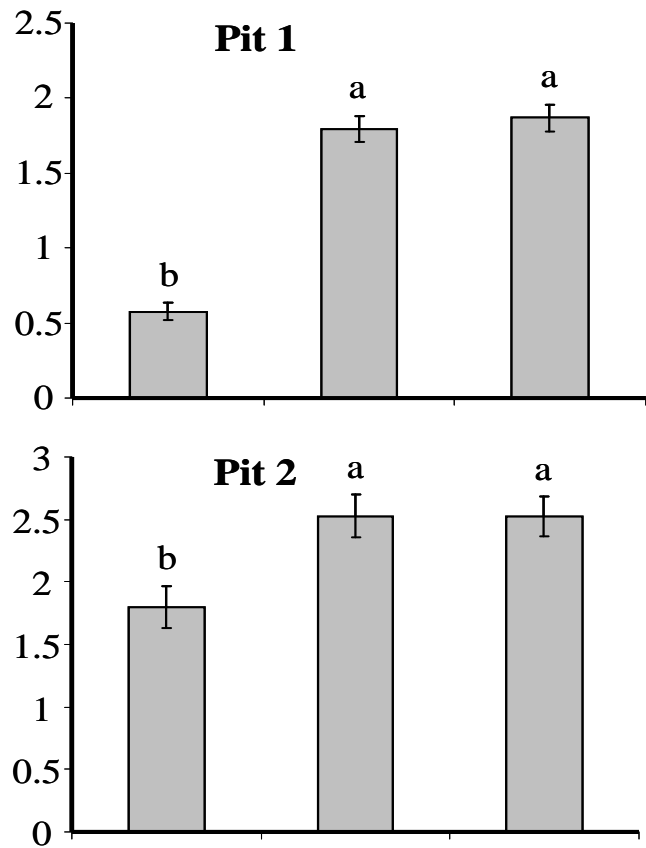

Pit 3

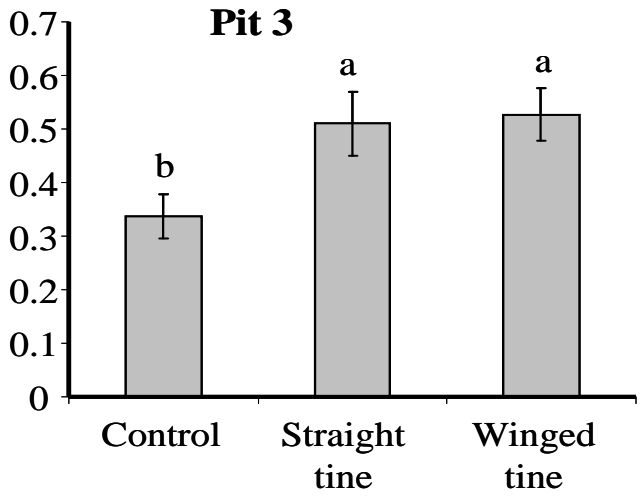

Figure 2 Mean penetration resistance (in Newtons) and root abundance scores of the three treatments in the upper profiles of Pit 1 (top), Pit 2 (middle), and Pit 3 (bottom) plots within Pit 1. Bars represent the standard error of the mean. Different letters denote significant difference between treatments at $\alpha=0.05$. Note the different scales in penetration resistance and root abundance scores between pits

Across all pits and in all treatments root abundance declined with increasing penetration resistance. The majority of roots $(71 \%)$ were located in zones within the profile where penetration resistance did not exceed $35 \mathrm{~N}$ (4.6 MPa). These zones were largely confined to the top $20 \mathrm{~cm}$ in control plots but extended much deeper into the profile in the ripping treatments resulting in a more gradual increase in penetration resistance and greater root abundance with depth (Figures 3 and 4).

Root abundance decreased substantially with increasing depth but roots were generally more abundant at every depth in the two ripping treatments than in the un-ripped control. This was also true for the upper $20 \mathrm{~cm}$ of the profile, with the exception of the top $10 \mathrm{~cm}$ in Pit 2. In Pits 1 and 2, mean root abundance was similar in both ripping treatments at all depths but there appeared to be an interaction in root abundance with depth between these treatments in Pit 3 . In the surface $10 \mathrm{~cm}$ roots were substantially more abundant in the straight tine treatment but from $30 \mathrm{~cm}$ and down to $60 \mathrm{~cm}$ roots were more abundant in the winged tine treatment (Figure 3). 


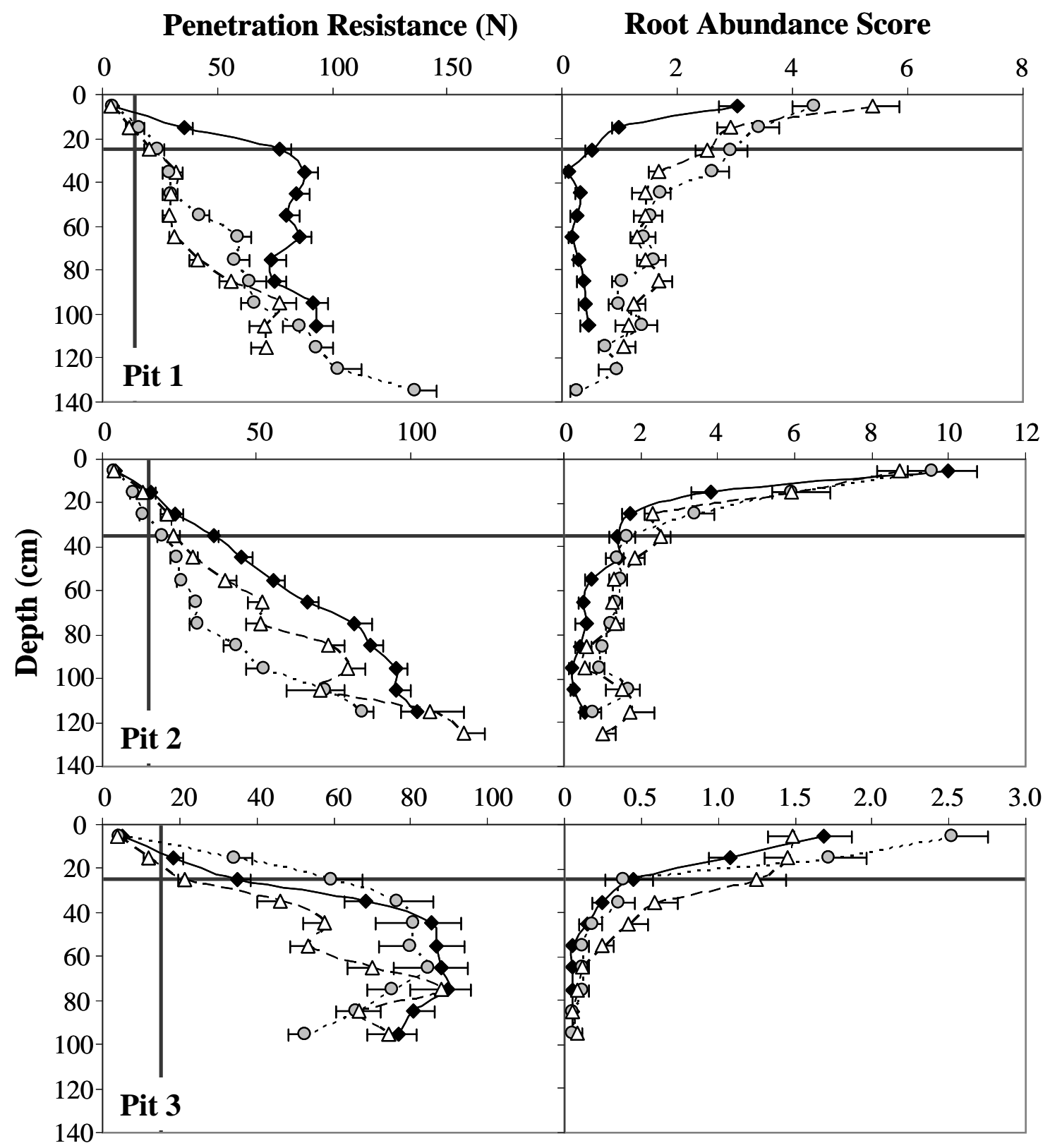

Figure 3 Change in mean penetration resistance (Newtons) and mean root abundance score with depth within straight tine ripped $(\cdots \circ)$, winged tine ripped $\left(-\Delta^{-}\right)$, and un-ripped control $(\longrightarrow-)$ plots in the three mine pits. Solid vertical lines indicate the generally accepted penetration resistance $(2 \mathrm{Mpa}$ or $15.3 \mathrm{~N})$ at which root growth of agricultural species is inhibited. Solid horizontal lines indicate the depth at which mean penetration resistance for all treatments becomes greater than $2 \mathrm{Mpa}$. Zero on the $\mathrm{y}$ axis represents the surface of the profile. Error bars represent one standard error of the mean. Note the different scales in penetration resistance and root abundance scores between pits 


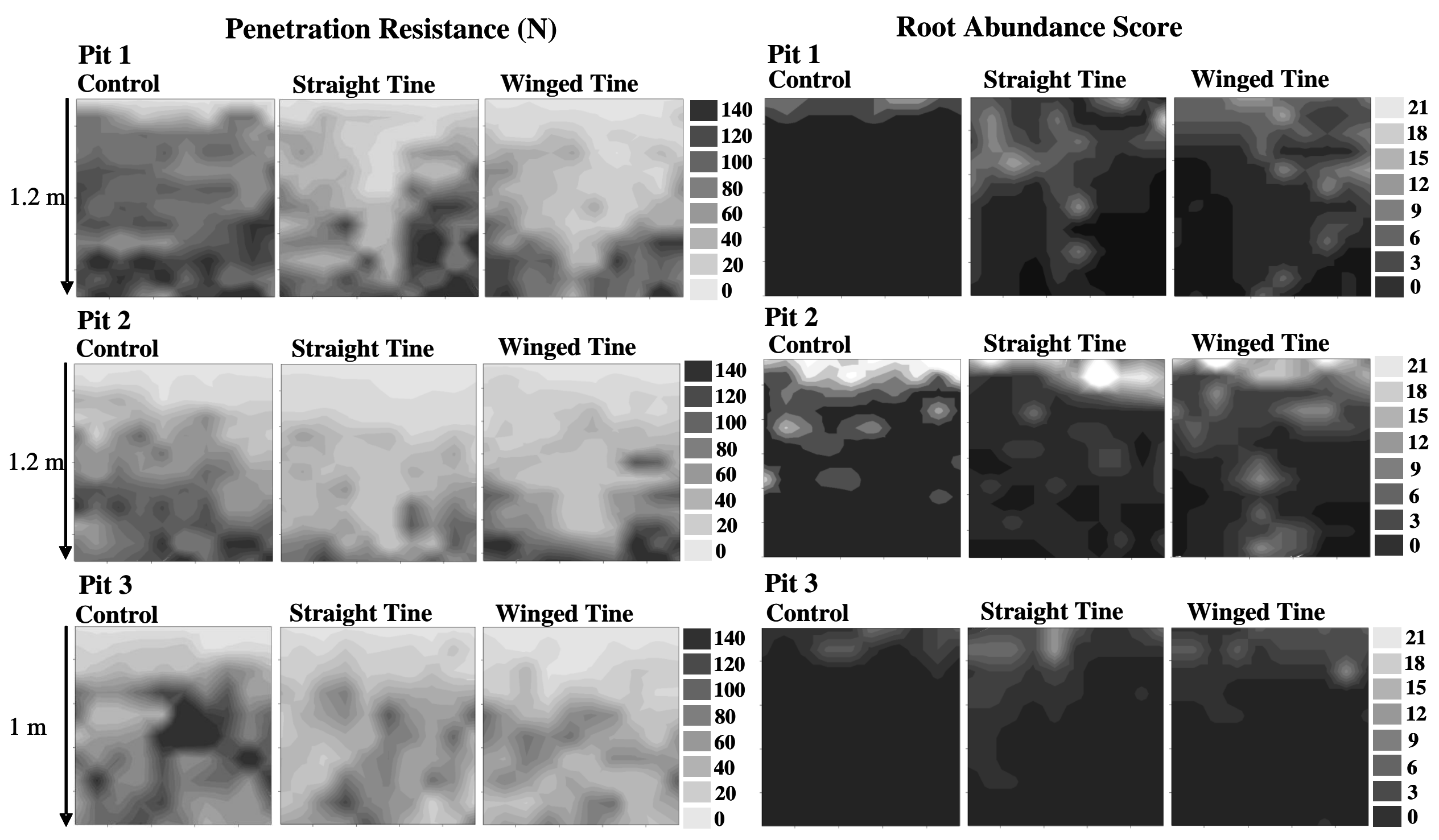

Figure 4 Spatial patterns of penetration resistance and root abundance in the upper profiles of un-ripped control (left), straight tine ripped (middle), and winged tine ripped (right) plots within Pit 1 (top), Pit 2 (middle), and Pit 3 (bottom) 


\section{Discussion}

Our results demonstrate that deep ripping has a significant and beneficial impact on root colonisation of post mining substrates within rehabilitated bauxite mine pits, irrespective of tine type. Pit floor deep ripping resulted in an overall reduction in soil strength and an accompanied increase in root abundance and there was evidence, consistent with that reported by Szota et al. (2007), that root growth was concentrated in and around the rip lines. These effects were evident in all of the examined pit floor materials; however, it appeared that some pit floor materials were more responsive to deep ripping than others.

The loams and silty clays of Pits 1 and 2 respectively, were very responsive to ripping. However, in the loamy materials of Pit 1 , the winged tine had a greater impact on penetration resistance and produced a broader zone of impact, whilst in the finer, more structurally stable silty clays of Pit 2 , the straight tine alleviated soil compaction more effectively than the winged tine. The coarse, sandy materials of Pit 3 did not respond as strongly to ripping. It was often not possible to identify the low strength $\mathrm{v}$-shaped zone that was characteristic of the rip-lines through the materials of the other two pits (Figure 4). In sandy materials, ripping with the straight tine produced no apparent reduction in penetration resistance. This may be the result of immediate backfill of the void created by the tine during ripping such that the narrower, straight tine has had little impact on soil strength. However, the naturally friable materials in Pit 3 were considerably more responsive to ripping with the winged tine, presumably due to its broader shape (Spoor, 2006).

Our initial assumption that the winged tine would have a greater impact than the straight tine in a broad range of regolith materials is not entirely supported by the results which suggest that tine performance varies with the materials being ripped. The winged tine significantly lowered penetration resistance in more friable, sandy soils, probably due to the greater area of impact it imparts on these materials in comparison with the straight tine. Conversely, the straight tine outperforms the winged tine in heavier, more clayey soils. The ripped profiles in Pit 2 demonstrate that the straight tine reduces penetration resistance to a greater extent in these materials whilst there is little difference in the width of impact between tine types. The greater cohesion of the clays in Pit 2 is probably responsible for this because it allows the straight tine to fracture a wider section than is possible in coarser materials (Spoor, 2006).

Despite the contrasting response to tine type in the strength of these different materials, there was no corresponding contrast in root proliferation; roots responded similarly to both tine types. The majority of roots growing within the examined profiles existed in zones where penetration resistance was lower than $35 \mathrm{~N}$ (4.6 MPa). In the control plots, these zones are generally restricted to the top $30 \mathrm{~cm}$ of the soil profile, but in deep ripped plots, these zones penetrate much deeper, occasionally down to $1 \mathrm{~m}$ or more. This accounts for differences in root proliferation between ripped plots and the non-ripped controls, but because the area of low penetration resistance is similar between tine types, differences in root proliferation are small, even if one tine type produced lower mean penetration resistances than the other. It appears that as long as soil strength is reduced to below a threshold of $35 \mathrm{~N}(4.6 \mathrm{MPa})$ over a sufficient area, roots will proliferate to a similar extent, regardless of whether there are zones of lower strength present. In comparison, other researchers have cited a penetration resistance of $2 \mathrm{MPa}(15.3 \mathrm{~N})$ as being critically limiting to root growth in woody agricultural species (Bengough et al., 2011; daSilva et al., 1994; Atwell, 1993), and northern hemisphere tree species (Sinnett et al., 2008) (see Figure 3). However, it seems likely that in the current study roots found in zones of higher strength are probably exploiting cracks or fissures within these zones and may not necessarily be growing through high strength soil despite high penetration resistance readings. Moreover, soil strength was assessed at only one point within each $10 \mathrm{~cm}^{2}$ grid cell, so penetrometer readings would not have detected the finer changes in the arrangement of peds and pores that have allowed root penetration after ripping in these high strength zones.

It is important to note that regions of higher soil strength that may impede root exploration to depth, may also lead to differences in plant survival under conditions of drought stress. Establishing vegetation growing on soil where penetration resistance is below levels that would hinder root access to deeper water stores will have a greater chance of surviving the summer drought that is typical of the local climate. Jarrah trees rely on these deeper water stores to survive the summer drought, and access it via sinker roots that pass through fissures in the lateritic duricrust and mottled zone of the unmined profile (Dell et al., 1983). Although the duricrust is removed during the mining process, zones of compacted subsoil in some post mining areas have nevertheless been shown to impede the penetration of jarrah roots to depth (Szota et al., 2007). Plants 
growing where root penetration is slowed by zones of high soil strength are likely to be at greater risk of drought related mortality (Ashby, 1997; Misra and Gibbons, 1996). The un-ripped control plots in this study could be susceptible to this effect as a result of significantly reduced root abundance and root penetration.

\section{References}

Ahmed, M.H. and Godwin, R.J. (1983) The influence of wing position on subsoiler penetration and soil disturbance, Journal of Agricultural Engineering Research, Vol. 28, pp. 489-492.

Ashby, W.C. (1997) Soil ripping and herbicides enhance tree and shrub restoration on stripmines, Restoration Ecology, Vol. 5, pp. 169-177.

Atwell, B.J. (1993) Response of roots to mechanical impedance, Environmental and Experimental Botany, 33, pp. $27-40$.

Bengough, A.G., McKenzie, B.M., Hallett, P.D. and Valentine, T.A. (2011) Root elongation, water stress, and mechanical impedance: a review of limiting stresses and beneficial root tip traits, Journal of Experimental Botany, Vol. 62, pp. 59-68.

Croton, J.T. and Ainsworth, G.L. (2007) Development of a winged tine to relieve mining related soil compaction after bauxite mining in Western Australia, Restoration Ecology 15 (supplement), pp. 48-53.

daSilva, A.P., Kay, B.D. and Perfect, E. (1994) Characterization of the least limiting water range of soils, Soil Science Society of America Journal, 58, pp. 1775-1781.

Dell, B., Bartle, J.R. and Tacey, W.H. (1983) Root occupation and root channels of jarrah forest subsoils, Australian Journal of Botany, Vol. 31, pp. 615-627.

Emerson, W.W. (2002) Emerson dispersion test, in N. McKenzie, K. Coughlan, and H. Cresswell (eds.) Soil Physical Measurement and Interpretation for Land Evaluation, CSIRO, Collingwood, pp. 190-199.

Gee, G.W. and Bauder, J.W. (1986) Particle size analysis, in A. Klute (ed), Methods of Soil Analysis (Vol 1): Physical and mineralogical methods, American Society of Agronomy, Madison, USA, pp. 383-412.

Godwin, R.J. (2007) A review of the effect of implement geometry on soil failure and implement forces, Soil and Tillage Research, Vol. 97, pp. 331-340.

Godwin, R.J. and Spoor, G. (1977) Soil failure with narrow tines, Journal of Agricultural Engineering Research Vol. 22, pp. 213-228.

Kew, G.A., Mengler, F.C. and Gilkes, R.J. (2007) Regolith strength, water retention, and implications for ripping and plant root growth in bauxite mine restoration, Restoration Ecology, Vol. 15 (supplement), pp. 54-64.

Koch, J.M. (2007) Alcoa's mining and restoration process in south Western Australia, Restoration Ecology Vol. 15 (supplement), pp. 11-16.

Lacey, S.T., Brennan, P.D. and Parekh, J. (2001) Deep may not be meaningful: cost and effectiveness of various ripping tine configurations in a plantation cultivation trial in eastern Australia, New Forests, Vol. 21, pp. 231-248.

McDonald, R.C. and Isbell, R.F. (1990) Soil Profile, in Australian soil and land survey field handbook, R.C. McDonald, R.F. Isbell, J.G. Speight, J. Walker and M.S. Hopkins (eds), Inkata Press, Melbourne, pp. 103-152.

Misra, R.K. and Gibbons, A.K. (1996) Growth and morphology of Eucalyptus seedling roots, in relation to soil strength arising from compaction, Plant and Soil, Vol. 182, pp. 1-11.

Moffat, A.J. and Boswell, R.C. (1997) The effectiveness of cultivation using the winged tine on restored sand and gravel workings, Soil and Tillage Research, Vol. 40, 111-124.

Rayment, G.E. and Higginson, F.R. (1992) Australian Laboratory Handbook of Soil and Water Chemical Methods, Inkata Press, Melbourne.

Sinnett, D., Morgan, G., Williams, M. and Hutchings, T.R. (2008) Soil penetration resistance and tree root development, Soil Use and Management, Vol. 24, pp. 273-280.

Spoor, G. (2006) Alleviation of soil compaction: requirements, equipment and techniques, Soil Use and Management, Vol. 22, pp. 113-122.

Spoor, G. and Godwin, R.J. (1978) An experimental investigation into the deep loosening of soil by rigid tines, Journal of Agricultural Engineering Research, Vol. 23, pp. 243-258.

Szota, C., Veneklaas, E.J., Koch, J.M. and Lambers, H. (2007) Root architecture of jarrah (Eucalyptus marginata) trees in relation to post-mining deep ripping in Western Australia, Restoration Ecology, Vol. 15 (supplement), pp. 65-73.

Tibbett, M. (2010) Large-scale mine site restoration of Australian eucalypt forests after bauxite mining: soil management and ecosystem development, in Ecology of Industrial Pollution, L.C. Batty and K.B. Hallberg (eds), Cambridge University Press, Cambridge, pp. 309-326. 